University of Montana

ScholarWorks at University of Montana

Numerical Terradynamic Simulation Group

Publications

Numerical Terradynamic Simulation Group

$11-2006$

\title{
Reconciling Carbon-cycle Concepts, Terminology, and Methods
}

F. S. Chapin III

G. M. Woodwell

J. Randerson

E. B. Rastetter

G. M. Lovett

See next page for additional authors

Follow this and additional works at: https://scholarworks.umt.edu/ntsg_pubs

Let us know how access to this document benefits you.

\section{Recommended Citation}

Chapin, F.S. III; Woodwell, G.M; Randerson, J.T.; Lovett, G.M.; Rastetter, E.B.; Baldocchi, D.D.; Clark, D.A.; Harmon, M.E.; Schimel, D.S.; Valentini R.; Wirth C.; Aber J.D.; Cole J.J.; Goulden M.L.; Harden J.W.; Heimann M.; Howarth R.W.; Matson P.A.; McGuire A.D.; Melillo J.M.; Mooney, H.A.; Neff, J.C.; Houghton, R.A.; Pace, M.L.; Ryan, M.G.; Running, S.W.; Sala, O.E.; Schlesinger, W.H.; Schulze, E. D. 2005. Reconciling carbon-cycle concepts, terminology, and methodology. Ecosystems. 9:1041-1050. doi: 10.1007/ s10021-005-0105-7

This Article is brought to you for free and open access by the Numerical Terradynamic Simulation Group at ScholarWorks at University of Montana. It has been accepted for inclusion in Numerical Terradynamic Simulation Group Publications by an authorized administrator of ScholarWorks at University of Montana. For more information, please contact scholarworks@mso.umt.edu. 


\section{Authors}

F. S. Chapin III, G. M. Woodwell, J. Randerson, E. B. Rastetter, G. M. Lovett, Dennis Baldocchi, D. A. Clark, M. E. Harmon, D. S. Schimel, R. Valentini, C. Wirth, J. D. Aber, J. J. Cole, M. L. Goulden, J. W. Harden, M. Heimann, Robert W. Howarth, P. A. Matson, A. D. McGuire, Jerry M. Melillo, H. A. Mooney, J. C. Neff, R. A.

Houghton, M. L. Pace, M. G. Ryan, Steven W. Running, Osvaldo E. Sala, W. H. Schlesinger, and E. D. Schulze 


\title{
Reconciling Carbon-cycle Concepts, Terminology, and Methods
}

\author{
F. S. Chapin III, ${ }^{1 *}$ G. M. Woodwell, ${ }^{2}$ J. T. Randerson, ${ }^{3}$ E. B. Rastetter, ${ }^{4}$ \\ G. M. Lovett, ${ }^{5}$ D. D. Baldocchi, ${ }^{6}$ D. A. Clark, ${ }^{7}$ M. E. Harmon, ${ }^{8}$ D. S. Schimel, ${ }^{9}$ \\ R. Valentini, ${ }^{10}$ C. Wirth, ${ }^{11}$ J. D. Aber, ${ }^{12}$ J. J. Cole ${ }^{5}$ M. L. Goulden, ${ }^{3}$ \\ J. W. Harden, ${ }^{13}$ M. Heimann, ${ }^{11}$ R. W. Howarth, ${ }^{14}$ P. A. Matson, ${ }^{15}$ \\ A. D. McGuire, ${ }^{16}$ J. M. Melillo, ${ }^{4}$ H. A. Mooney, ${ }^{17}$ J. C. Neff, ${ }^{18}$ \\ R. A. Houghton, ${ }^{2}$ M. L. Pace, ${ }^{5}$ M. G. Ryan, ${ }^{18}$ S. W. Running, ${ }^{19}$ O. E. Sala, ${ }^{20}$ \\ W. H. Schlesinger, ${ }^{21}$ and E.-D. Schulze ${ }^{11}$
}

\begin{abstract}
${ }^{1}$ Institute of Arctic Biology, University of Alaska-Fairbanks, Fairbanks, Alaska 99775, USA; ${ }^{2}$ The Woods Hole Research Center, Woods Hole, Massachusetts 02543, USA; ${ }^{3}$ Department of Earth System Science, University of California, Irvine, California 92697 , USA ${ }^{4}$ The Ecosystem Center, Marine Biological Laboratory, Woods Hole, Massachusetts 02543, USA; ${ }^{5}$ Institute of Ecosystem Studies, Millbrook, New York 12545, USA; ${ }^{B}$ Department of Environmental Science, Policy, and Management, University of California, Berkeley, California 94720, USA; ${ }^{7}$ Department of Biology, University of Missouri, St. Louis, Missouri 63121-4499, USA; ${ }^{8}$ Department of Forest Science, Oregon State University, Corvallis, Oregon 97331-5752, USA; ${ }^{9}$ National Center for Atmospheric Research, Boulder, Colorado 80305, USA; ${ }^{10}$ Department of Forest Science and Environment, University of Tuscia, I-01100, Viterbo, Italy; ${ }^{11}$ Max-PlanckInstitute for Biogeochemistry, D-07701 Jena, Germany; ${ }^{12}$ Complex Systems Research Center, University of New Hampshire, Durham, New Hampshire 03824, USA; ${ }^{3}$ US Geological Survey, Menlo Park, California 94025, USA; ${ }^{14}$ Department of Ecology and Evolutionary Biology, Cornell University, Ithaca, New York 14853, USA; ${ }^{15}$ Department of Geological and Environmental Sciences, Stanford University, Stanford, California 94305-2115, USA; ${ }^{16}$ US Geological Survey, Alaska Cooperative Fish and Wildlife Research Unit, University of Alaska-Fairbanks, Fairbanks, Alaska 99775, USA; ${ }^{17}$ Department of Biological Sciences, Stanford University, Stanford, California 94305-2115, USA; ${ }^{18}$ Geological Sciences and Environmental Studies, University of Colorado, Boulder, Colorado 80309, USA; ${ }^{19}$ Rocky Mountain Research Station, USDA Forest Service, Fort Collins, Colorado 80526-2098, USA; ${ }^{20}$ Department of Ecology and Evolutionary Biology, Brown University, Providence, Rhode Island 02912, USA; and ${ }^{21}$ Nicholas School of the Environment and Earth, Duke University, Durham, North Carolina 27708-0329, USA
\end{abstract}

\begin{abstract}
Recent projections of climatic change have focused a great deal of scientific and public attention on patterns of carbon (C) cycling as well as its controls, particularly the factors that determine whether an ecosystem is a net source or sink of atmospheric carbon dioxide $\left(\mathrm{CO}_{2}\right)$. Net ecosystem production (NEP), a central concept in C-cycling research, has been used by scientists to represent two different concepts. We propose that NEP be restricted to just one of its two original definitions-the imbalance between gross primary production (GPP) and ecosystem respiration (ER). We further propose that a new term-net ecosystem carbon balance (NECB)-be applied to the net rate of $\mathrm{C}$ accumula-
\end{abstract}

Received 13 July 2005; accepted 6 January 2006; published online 17 November 2006.

*Corresponding author; e-mail: ferry.chapin@uaf.edu tion in (or loss from [negative sign]) ecosystems. Net ecosystem carbon balance differs from NEP when C fluxes other than $C$ fixation and respiration occur, or when inorganic $C$ enters or leaves in dissolved form. These fluxes include the leaching loss or lateral transfer of $\mathrm{C}$ from the ecosystem; the emission of volatile organic $\mathrm{C}$, methane, and carbon monoxide; and the release of soot and $\mathrm{CO}_{2}$ from fire. Carbon fluxes in addition to NEP are particularly important determinants of NECB over long time scales. However, even over short time scales, they are important in ecosystems such as streams, estuaries, wetlands, and cities. Recent technological advances have led to a diversity of approaches to the measurement of $C$ fluxes at different temporal and spatial scales. These approaches frequently capture different components of NEP or NECB and can therefore be compared across scales only by carefully specifying the 
fluxes included in the measurements. By explicitly identifying the fluxes that comprise NECB and other components of the $\mathrm{C}$ cycle, such as net ecosystem exchange (NEE) and net biome production (NBP), we can provide a less ambiguous framework for understanding and communicating recent changes in the global C cycle.
Key words: net ecosystem production; net ecosystem carbon balance; gross primary production; ecosystem respiration; autotrophic respiration; heterotrophic respiration; net ecosystem exchange; net biome production; net primary production.

\section{INTRODUCTION}

Carbon (C) constitutes about half of the dry mass of life on earth and the organic matter that accumulates in soils and sediments when organisms die. Its central role in the biogeochemical processes of ecosystems has therefore always been of keen interest to ecosystem ecologists (Lindeman 1942; Odum 1959; Ovington 1962; Rodin and Bazilevich 1967; Woodwell and Whittaker 1968; Fisher and Likens 1973; Lieth 1975). In recent decades, an even broader community of scientists and policy makers has become interested in understanding the controls over $\mathrm{C}$ cycling, because it has become abundantly clear that the biological and physical controls over $\mathrm{C}$ absorption, sequestration, and release by ecosystems strongly influence the carbon dioxide $\left(\mathrm{CO}_{2}\right)$ concentration and heat-trapping capacity of the atmosphere and thus the dynamics of the global climate system (Woodwell and Mackenzie 1995; Wigley and others 1996; Cox and others 2000; Prentice and others 2001; Fung and others 2005). As part of the 1997 Kyoto Protocol to the United Nations Framework Convention on Climate Change, countries may use increases in C storage by ecosystems as one way to meet the mandated reductions in $\mathrm{C}$ emissions produced by the burning of fossil fuels. As a result, they now have a huge economic and political stake that is contingent on understanding the controls over $\mathrm{C}$ inputs to and outputs from by ecosystems.

Given the central role of the $\mathrm{C}$ cycle in climate change and the breadth of disciplines involved in its study, it is important that C-cycling concepts and terminology be clearly defined. Ecosystems are important sources and sinks of $\mathrm{C}$, so it is critical to define unambiguously whether a system or region releases or absorbs $\mathrm{CO}_{2}$ from the atmosphere. Lovett and others (2006) point out that net ecosystem production (NEP), the central term used to describe imbalances in $C$ uptake and loss by ecosystems, has been used to represent two distinct concepts in the C-cycling literature, leading to miscommunication and potential confusion.
In this paper, we briefly review some of the historical, methodological, and conceptual roots of the differences in C-cycling questions and approaches and suggest a common framework and terminology for studying $C$ cycling in ecosystems. Our goal is to clarify concepts and definitions within a common conceptual framework and to point out persisting ambiguities that require further research.

\section{Net Ecosystem Production and Carbon Accumulation Rates in Ecosystems}

Net ecosystem production (NEP) was initially defined by Woodwell and Whittaker (1968) in two ways: (a) as the difference between ecosystem-level photosynthetic gain of $\mathrm{CO}_{2}-\mathrm{C}$ (gross primary production, or GPP) and ecosystem (plant, animal, and microbial) respiratory loss of $\mathrm{CO}_{2}-\mathrm{C}$ (ecosystem respiration, or ER) and (b) as the net rate of $C$ accumulation in ecosystems. This represented the core of an elegant but simple ecosystem model in which the rate of $\mathrm{C}$ accumulation in an ecosystem resulted from the imbalance of photosynthesis and ecosystem respiration. Earlier, Odum (1956) had linked concepts of $C$ cycling and energy flow and pointed out that ecosystems often accumulate $C$ when GPP exceeds ER (that is, when GPP/ER is greater than one) (autotrophic ecosystems) or lose C when GPP/ER is less than one (heterotrophic ecosystems). In other ecosystems, such as cities and streams, lateral flows of $\mathrm{C}$ and energy can be the major determinants of net ecosystem $C$ balance regardless of whether the ecosystem is autotrophic or heterotrophic (Fisher and Likens 1973). This raises questions about the nature of linkages between GPP, ER, and the net accumulation of $C$ in ecosystems.

Woodwell and Whittaker (1968) developed their concept of NEP in the context of a 50-60year-old-mid/late successional forest in which photosynthetic gain and ER were assumed to be the dominant fluxes responsible for $\mathrm{C}$ accumulation. As a global long-term average, this is a reasonable approximation, because the annual 
storage of $\mathrm{C}$ in soils in chronosequences of at least 1000 years is only about $0.5 \%$ of net primary production (NPP) (photosynthesis minus the respiration of primary producers), indicating that various respiratory processes and other loss pathways are quite efficient at burning up organic $C$ (Schlesinger 1990). A similar quantity of $C$ is annually transported by rivers from land to oceans and is balanced by a release of $\mathrm{CO}_{2}$ from the oceans and subsequent uptake by terrestrial ecosystems, leaving the land close to steady state prior to the Anthropocene (Schlesinger and Melack 1981; Aumont and others 2001). However, when the concept of NEP is applied to a broad array of ecosystems and time scales, dissolved, volatile, and depositional organic and inorganic $C$ fluxes other than GPP and ER are often substantial. Therefore, the imbalance between GPP and ER does not, as a generality, equal net $\mathrm{C}$ accumulation rate in ecosystems (Fisher and Likens 1973; Rosenbloom and others 2001; Randerson and others 2002; Lovett and others 2006). In the wake of increasing recognition that GPP minus ER does not equal net $C$ accumulation rate, some authors have defined NEP primarily as net $C$ accumulation rate (Aber and Melillo 1991; Sala and Austin 2000; Chapin and others 2002; Randerson and others 2002), whereas others have defined it as the imbalance between GPP and ER (Schlesinger 1997; Howarth and Michaels 2000; Aber and Melillo 2001; Falge and others 2002), leading to confusion about what NEP estimates in the literature actually represent.

Cursory searches of the phrase "net ecosystem production" in the Web of Science and JSTOR indicate that disciplines differ in their prevailing definition of the term. In general, aquatic and atmospheric scientists have defined NEP as GPP - ER, whereas terrestrial ecologists have defined NEP as either the net $C$ accumulation rate or simultaneously as both GPP - ER and the net C accumulation rate. Initial discussions among authors of the present paper revealed similar disagreement about how Woodwell and Whittaker (1968) had initially defined NEP and what this term should represent today. However, if the NEP concept is to be useful in communicating among researchers who study different components of an integrated landscape, scientists must agree on a single definition.

We support the suggestion of Lovett and others (2006) that NEP be defined as GPP - ER. Defined in this way. NEP is conceptually simple and analogous to NPP (photosynthesis minus the respiration of primary producers). It can therefore be unam- biguously incorporated into biogeochemical models and is independent of the continually evolving technology of measuring the components of ecosystem $C$ budgets. We propose that the term net ecosystem carbon balance (NECB) be applied to the net rate of $C$ accumulation in (or loss from [negative sign]) ecosystems. NECB represents the overall ecosystem $C$ balance from all sources and sinks-physical, biological, and anthropogenic:

$$
\mathrm{NECB}=\mathrm{dC} / \mathrm{dt}
$$

Net fluxes of several forms of $C$ contribute to NECB:

$\mathrm{NECB}=-\mathrm{NEE}+\mathrm{F}_{\mathrm{CO}}+\mathrm{F}_{\mathrm{CH} 4}+\mathrm{F}_{\mathrm{VOC}}+\mathrm{F}_{\mathrm{DIC}}+\mathrm{F}_{\mathrm{DOC}}+\mathrm{F}_{\mathrm{PC}}$

where NEE is net ecosystem exchange (the net $\mathrm{CO}_{2}$ flux from the ecosystem to the atmosphere (or net $\mathrm{CO}_{2}$ uptake [positive sign]); $\mathrm{F}_{\mathrm{CO}}$ is net carbon monoxide (CO) absorption (or efflux [negative sign]); $\mathrm{F}_{\mathrm{CH} 4}$ is net methane $\left(\mathrm{CH}_{4}\right)$ consumption (or efflux [negative sign]); $F_{v o c}$ is net volatile organic $\mathrm{C}\left(\mathrm{VOC}\right.$ ) absorption (or efflux [negative sign]); $\mathrm{F}_{\mathrm{DIC}}$ is net dissolved inorganic $C$ (DIC) input to the ecosystem (or net DIC leaching loss [negative sign]); $F_{D O C}$ is net dissolved organic $C$ (DOC) input (or net DOC leaching loss [negative sign]); and $\mathrm{F}_{\mathrm{PC}}$ is the net lateral transfer of particulate (nondissolved, nongaseous) $C$ into the ecosystem (or out of [negative sign]) by processes such as animal movement, soot emission during fires, water and wind deposition and erosion, and anthropogenic transport or harvest. Extrapolation of NECB to larger spatial scales has been termed "net biome productivity" (NBP) (Schulze and Heimann 1998).

\section{A Common Conceptual Framework}

To place NEP and NECB in a common conceptual framework, it is useful to conceptualize the ecosystem as a volume with explicitly defined top, bottom, and sides (Randerson and others 2002) (Figure 1). In terrestrial ecosystems, the top of this defined volume is typically above the canopy and the bottom is below the rooting zone. In aquatic ecosystems, the top of the ecosystem is typically the air-water interface (or sometimes the sedimentwater interface) and the bottom is either beneath the sediments or somewhere within the water column. In streams and rivers, this ecosystem may be defined with reference to a moving parcel of water or to stationary points in the streambed. Net ecosystem carbon balance equals the total $C$ input minus the total $C$ output from the ecosystem over a specified time interval. 


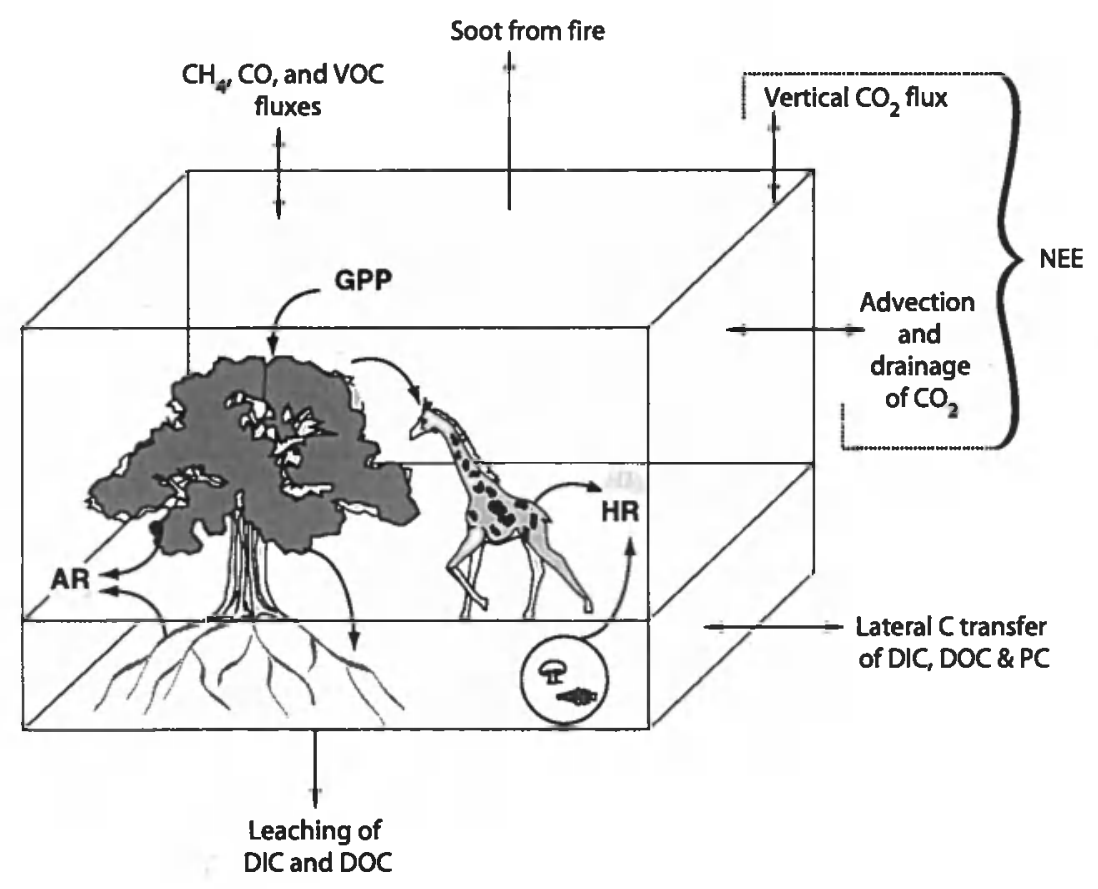

Figure 1. Relationship among the carbon (C) fluxes that determine net ecosystem carbon balance (NECB) (the net of all C imports to and exports from the ecosystem) and the fluxes (in bold) that determine net ecosystem production (NEP). The box represents the ecosystem. Fluxes contributing to NECB are emissions to or uptake from the atmosphere of carbon dioxide $\left(\mathrm{CO}_{2}\right)$ (net ecosystem exchange, or NEE), methane $\left(\mathrm{CH}_{4}\right)$, carbon monoxide (CO), and volatile organic $\mathrm{C}$ (VOC); lateral or leaching fluxes of dissolved organic and inorganic $\mathrm{C}$ (DOC and DIC, respectively); and lateral or vertical movement of particulate C (PC) (nongaseous, nondissolved) by processes such as animal movement, soot emission during fires, water and wind deposition and erosion, and anthropogenic transport or harvest. Fluxes contributing to NEP are gross primary production (GPP), autotrophic respiration (AR), and heterotrophic respiration (HR).

On short time scales, GPP and ER (that is, the components of NEP) are the processes that typically consume and produce, respectively, most of the inorganic $\mathrm{C}$ in an ecosystem. In the light, for example, GPP typically exceeds ER, resulting in a positive NEP. This reduces the concentration of $\mathrm{CO}_{2}$ and/or DIC inside the ecosystem and generates a diffusion gradient that causes $\mathrm{CO}_{2}$ to enter the ecosystem from the atmosphere (a negative NEE). Conversely, in the dark, ER typically dominates $\mathrm{CO}_{2}$ exchange, resulting in a negative NEP. This increases the concentration of $\mathrm{CO}_{2}$ and/or DIC inside the ecosystem and generates a diffusion gradient that causes $\mathrm{CO}_{2}$ to move from the ecosystem to the atmosphere (a positive NEE). Thus, over short time scales, GPP and ER are two of the key processes that drive NECB, and [-NEE] often closely approximates both NEP and NECB in many ecosystems (Baldocchi 2003). (Note that, by convention, NEE is opposite in sign to NEP and NECB because NEE is defined by atmospheric scientists as a $C$ input to the atmosphere, whereas NEP and NECB are defined by ecologists as $C$ inputs to ecosystems).
Nonetheless, different types of ecosystems may be dominated by radically different $\mathrm{C}$ fluxes, particularly over the long term. There are several general reasons why [-NEE], NEP, and NECB may diverge from one another.

Because NEE is, by definition, the $\mathrm{CO}_{2}$ flux from the ecosystem to the atmosphere, [-NEE] diverges from NEP and NECB when inorganic C enters or leaves an ecosystem as DIC in the aquatic phase rather than through atmospheric exchange. Leaching of groundwater, for example, generally transfers respiration-derived DIC from terrestrial to aquatic ecosystems, causing [-terrestrial NEE] to be greater than terrestrial NEP or NECB and [-aquatic NEE] to be less than aquatic NEP or NECB. On short time scales, this discrepancy is often small, but on an annual basis it can be substantial. About $20 \%$ of terrestrial NEP in arctic Alaska, for example, is transferred to aquatic ecosystems as DIC (Kling and others 1991). Similarly, upwelling and other vertical or horizontal mixing of water masses can move DIC among aquatic ecosystems in patterns that are not reflected in NEE. 
Because NEP is, by definition, the inorganic $C$ exchange of an ecosystem caused by GPP and ER, NECB diverges from NEP when $C$ enters or leaves ecosystems in forms other than $\mathrm{CO}_{2}$ or DIC. Other important fluxes include leaching loss from (or input to) the ecosystem of DOC; emission of $\mathrm{CH}_{4}, \mathrm{CO}$, and VOCs; erosion; fire; harvest; and other vertical and lateral $\mathrm{C}$ transfers (Schlesinger 1997; Stallard 1998; Guenther 2002; Randerson and others 2002). In streams, rivers, and estuaries, lateral $C$ transfers among ecosystems often dominate NECB (Fisher and Likens 1973; Howarth and others 1996; Richey and others 2002). Some ecosystems with large lateral $C$ imports (for example, cities, estuaries, and some lakes) can be a net $\mathrm{CO}_{2}$ source to the atmosphere. In lakes, rivers, and oceans, physical processes such as $\mathrm{CO}_{2}$ solubility, vertical mixing rates, and sedimentation of particulate organic $C$ (POC) often dominate the $\mathrm{C}$ budget (Lovett and others 2006).

Net ecosystem carbon balance also diverges from NEP when inorganic $C$ enters or leaves ecosystems for reasons other than an imbalance between GPP and ER. The largest nonrespiratory oxidations of organic matter to inorganic $C$ are by fire in terrestrial ecosystems and by ultraviolet radiation in aquatic ecosystems. Some ecosystems accumulate inorganic $\mathrm{C}$-for example, desert caliche (typically less than $5 \mathrm{~g} \mathrm{C} \mathrm{m}^{-2} \mathrm{Y}^{-1}$ ) (Schlesinger 1985)-or show small gains in inorganic $\mathrm{C}$ associated with the weathering of carbonate rocks (less than 3\% of NPP) (Andrews and Schlesinger 2001). These inorganic $C$ accumulation rates are captured in NECB but not NEP and are typically small.

The processes responsible for divergence between [-NEE], NEP, and NECB change with temporal and spatial scale. The Earth system (The Earth plus the atmosphere) has a positive NEE (increase in atmospheric $\mathrm{CO}_{2}$ ) during transitions from glacial to the interglacial conditions due to the recruitment of $\mathrm{C}$ from largely inactive pools, such as the deep ocean and permafrost. Similarly, the positive NEE of the Earth system during the Anthropocene reflects the movement from geologic sources (coal and oil) to the atmosphere. This movement has been partially offset by a positive NEP and NECB (and a negative NEE) in forests and oceans (Schimel 1995). On time scales of a century or more vegetation development during succession is associated with a positive NEP and NECB (and a negative NEE). During fires, there is a brief time when NEP is zero (no photosynthesis or respiration), but NECB decreases and NEE increases dramatically.
Immediately after fire, [-NEE], NEP, and NECB decline in synchrony because decomposition exceeds photosynthesis.

As efforts develop to integrate estimates of NECB across heterogeneous landscapes containing terrestrial, freshwater, and marine ecosystems or to compare measurements made at different temporal scales, it becomes crucial that the same combinations of fluxes are being compared. As a start, the key C fluxes (for example, GPP, ER, NPP, NEP, and NECB) must have the same units (for example, $\mathrm{kg} \mathrm{C} \mathrm{ha}{ }^{-1} \mathrm{Y}^{-1}$ ) and be calculated in a manner that is independent of temporal and spatial scale, so estimates can be readily compared across scales. However, as we have pointed out, different types of ecosystems are dominated by radically different fluxes, and the techniques used to estimate them are quite scale-dependent. Any estimate of NEP or NECB from field observations should therefore specify explicitly which fluxes are included in the estimate and which fluxes are unmeasured or assumed to be negligible.

\section{Clarifying Carbon-cycling Concepts}

Although this minireview focuses on NEP and NECB, similar ambiguities cloud the use of other central concepts in the $\mathrm{C}$ cycle. We offer the following conventions in defining some of the central concepts and point out unresolved issues that still complicate the use and interpretation of these terms.

Gross primary production (GPP) is the sum of gross $\mathrm{C}$ fixation by autotrophic $\mathrm{C}$-fixing tissues per unit ground or water area and time. Because our emphasis here is on the $C$ budget of ecosystems, we include both photosynthesis and chemoautotrophy in GPP. However, because the energy that drives chemoautotrophy is either completely (reduced substrate plus oxygen $\left[\mathrm{O}_{2}\right]$ or other oxidants in sediments) or partly $\left(\mathrm{O}_{2}\right.$ or other oxidants in geothermal vents) derived from photosynthesis, we recognize that from an energetic perspective chemoautotrophy is better classified as a component of secondary production, rather than GPP (Howarth and Teal 1980; Howarth 1984). Although chemoautotrophy is a small component of $\mathrm{CO}_{2}$ fixation globally, locally it can be a very important component of the C budget (Howarth 1984; Jannasch and Mottl 1985).

Autotrophic respiration (AR) is the sum of respiration ( $\mathrm{CO}_{2}$ production) by all living parts of primary producers per unit ground or water area and time. The extent to which rhizosphere microbes and mycorrhizae contribute to measured "root respiration" is uncertain. It is even unclear whether these 
root-associated microbial fluxes should be considered part of autotrophic or heterotrophic respiration. Lumping rhizosphere microbes, mycorrhizal fungi, and bacteria of $\mathrm{N}$-fixing nodules with other heterotrophs is conceptually cleaner, but their impact on plant nutrition and $\mathrm{C}$ balance and the measurement of their respiration rates are difficult to separate from other root functions.

Heterotrophic respiration (HR) is the respiration rate of heterotrophic organisms (animals and microbes) summed per unit ground or water area and time.

Ecosystem respiration (ER) is the respiration of all organisms summed per unit ground or water area and time.

Net ecosystem production (NEP) is GPP minus ER. In pelagic systems of lakes and oceans NEP can be measured directly by enclosing the ecosystem in a jar or measuring diel changes in dissolved oxygen or $\mathrm{CO}_{2}$ (Howarth and Michaels 2000; Hanson and others 2003). Interestingly, the measurement of NEP is more robust than calculations of GPP and ER, which depend on the assumption that respiration measured in the light is the same as that measured in the dark, a relationship that appears to be variable (Roberts and others forthcoming).

In contrast to aquatic ecosystems, the structural complexity of terrestrial ecosystems creates challenges for the direct measurement of NEP, so terrestrial ecologists have focused on estimates of GPP and ER based on gas exchange. Calculation of NEP from these fluxes assumes that foliar respiration and the temperature response of ER are the same during the day as at night. These assumptions are questionable because photorespiration in chloroplasts, which occurs only in the light, is compensated to an unknown extent by down-regulation of mitochondrial respiration in the light (Kirschbaum and Farquhar 1984) or by the use of the respired $\mathrm{CO}_{2}$ in photosynthesis (Loreto and others 1999, 2001). These uncertainties are analogous to those confronted by aquatic ecologists in calculating GPP and ER from NEP.

Net ecosystem exchange (NEE) is the net $\mathrm{CO}_{2}$ exchange with the atmosphere-that is, the vertical and lateral $\mathrm{CO}_{2}$ flux from the ecosystem to the atmosphere (Baldocchi 2003). There are occasions of high atmospheric stability when $\mathrm{CO}_{2}$ exchange by the ecosystem may not reach the eddy covariance measurement system; in this case, a storage term is added, which is the vertical integral of $\mathrm{dC} / \mathrm{dt}$, measured with a $\mathrm{CO}_{2}$ profile system at two points in time. The storage term can also be used to identify lateral advection, if the buildup of $\mathrm{CO}_{2}$ in the stand is less than would be expected from soil respiration (Aubinet and others 2003). When advection occurs, NEE differs from the vertical canopy flux measured by eddy covariance. Net ecosystem exchange differs from NEP in being opposite in sign, in omitting gains and losses of respiration-derived DIC, and in including nonrespiratory $\mathrm{CO}_{2}$ fluxes such as those from fire or ultraviolet oxidation of organic matter (Figure 1). Net ecosystem exchange approaches NEP (= GPP - ER) (but is opposite in sign), when these other fluxes and changes in inorganic $\mathrm{C}$ storage within the ecosystem are small.

Net primary production (NPP) is GPP - AR. It includes not only the growth of primary producers (biomass accumulation and tissue turnover above and belowground in terrestrial ecosystems) but also the $C$ transfer to herbivores and root symbionts (for example, mycorrhizal fungi), the excretion of organic $C$ from algae, and the production of root exudates and plant VOCs (Long and others 1989; Clark and others 2001; Kesselmeier and others 2002). Published summaries of data on terrestrial NPP are, however, usually based on data from litterfall and aboveground biomass accumulation and therefore are not closely aligned to the concept of NPP as the imbalance between GPP and AR (Clark and others 2001). Estimates of NPP in aquatic ecosystems based on ${ }^{14} \mathrm{C}$ are intermediate to the theoretical rates of NPP and GPP because phytoplankton respire some but not all of the newly fixed, ${ }^{14} \mathrm{C}$-labeled organic C (Peterson 1980; Howarth and Michaels 2000).

Net ecosystem carbon balance (NECB) is the net rate of organic plus inorganic $\mathrm{C}$ accumulation in (or loss from [negative sign]) an ecosystem, regardless of the temporal and spatial scale at which it is estimated. It can be measured directly in terrestrial ecosystems, particularly over long time scales, as the change in total $C$ in the ecosystem over the measured time interval. In early successional and managed ecosystems, changes in $C$ stocks may be detectable in years to decades (Matson and others 1997; Richter and others 1999), but in most other ecosystems $\mathrm{C}$ stocks change too slowly to be detected easily, given their substantial spatial variability.

Net biome production (NBP) is NECB estimated at large temporal and spatial scales. The concept was developed to account for many of the fluxes seldom measured by NEE and explicitly includes disturbances such as fire that remove $C$ from the system via nonrespiratory processes in addition to disturbances that redistribute $\mathrm{C}$ from the biomass into detrital pools (Schulze and Heimann 1998; Schulze and others 1999, 2000). Net biome 


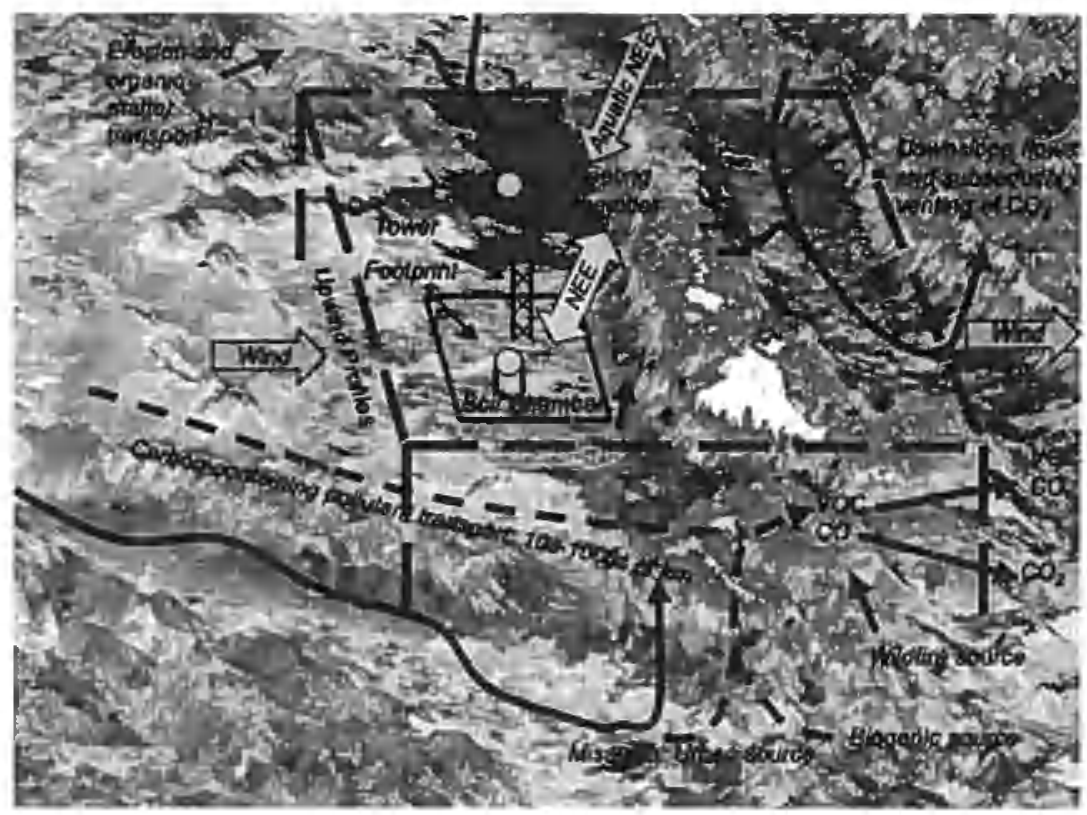

Figure 2. The relationship of carbon (C) fluxes to current measurement approaches. The background landscape image represents daily average gross primary production (GPP) in Montana, USA, computed from MODIS satellite estimates of intercepted photosynthetically active radiation data at $250-\mathrm{m}$ spatial resolution. Also shown are some of the vertical and horizontal $\mathrm{C}$ fluxes that add complexity (and are not incorporated) in this satellite-based $\mathrm{C}$-flux estimate, including erosion, inputs and export of $\mathrm{C}$ as methane $\left(\mathrm{CH}_{4}\right)$, carbon monoxide (CO), and volatile organic $\mathrm{C}$ (VOC), and lateral flow of respired carbon dioxide $\left(\mathrm{CO}_{2}\right)$ downslope, all factors that can confound measurements, depending on the scale. $\mathrm{A}$ floating aquatic chamber captures aquatic net ecosystem exchange (NEE); this (with a negative sign) is equivalent to net ecosystem production (NEP) (which is equal to gross primary production [GPP] minus ecosystem respiration [ER] plus $\mathrm{CO}_{2}$ derived from terrestrial dissolved inorganic $C$ (DIC) that entered the lake in groundwater. A soil chamber captures belowground components of terrestrial heterotrophic and autotrophic respiration. An eddy covariance tower captures the vertical component of terrestrial NEE; this (with a negative sign) is equivalent to NEP, when corrected for canopy storage, the advective flow of $\mathrm{CO}_{2}$ from the forest to the valley, and leaching loss of respiration-derived DIC to the lake. The boundary-layer $\mathrm{C}$ budget, measured by aircraft and computed from differences in upwind and downwind $\mathrm{CO}_{2}$ inventories, provides a sample of landscape-integrated (terrestrial and aquatic) NEE; it is also affected by remote sources, local disturbance fluxes and urban pollution; if lateral fluxes of DIC are small, NEE (with a negative sign) closely approximates NEP. Net ecosystem carbon balance (NECB) can be estimated from sequential measurements of ecosystem $C$ stocks over time, but these changes are often too small to be detected except in very homogeneous ecosystems that are rapidly gaining or losing C. Measured fluxes can be compared with model inversions that calculate NECB at large scales (equivalent to net biome production [NBP]) from the geographic patterns of net $\mathrm{CO}_{2}$ sources or sinks that would be required to produce observed patterns of atmospheric $\mathrm{CO}_{2}$ transport. Because there is rarely a one-to-one correspondence between measurement techniques and conceptual fluxes, precision is required in defining both the conceptual fluxes and what is being measured as a function of method and scale.

production can thus be viewed as the spatial and temporal average of NECB over a heterogeneous landscape:

$$
N B P=\frac{\int_{T} \int_{A} N E C B(x, t) d x d t}{T \cdot A}
$$

where $A$ is the land surface area considered, $T$ is the temporal extent of the integration, and $x$ and $t$ are the spatial and temporal coordinates. Because NECB can be estimated at any temporal and spatial scale, it facilitates cross-scale comparisons between short-term flux measurements and long-term C accumulation estimates, whereas NBP applies explicitly to large scales (Schulze and others 2002; Ciais and others 2005). One of the greatest challenges in refining the global $\mathrm{C}$ budget is to scale from short-term measurements on relatively homogeneous flat terrain to large topographically heterogeneous regions, where long-term $C$ budgets are strongly influenced by spatial interactions among ecosystems (such as lateral air drainage and erosion) and rare events (such fire and insect outbreaks). 


\section{Conclusions and NeXt Steps}

The construction of an integrated $\mathrm{C}$ budget is challenging because many commonly used methods incorporate some, but not all, of the fluxes we have defined above. Lack of data on key ecosystem $C$ fluxes such as root production often lead to the incorporation of literature values or model estimates that may or may not be transferable among ecosystems, suggesting the need for caution and redundant approaches in developing $C$ budgets. In addition, some methods contain consistent biases that make it difficult to link the results with other flux estimates. For example, lateral air drainage at night can lead to underestimates of nighttime ecosystem respiration in eddy covariance measurements (Aubinet and others 2003); measurements of ${ }^{14} \mathrm{CO}_{2}$ incorporation and gas exchange capture different components of the balance between GPP and AR. Because the estimates obtained for a particular flux depend strongly on the method and time scale of measurement, these components should be specified (for example, hourly GPP, daily AR, annual NPP).

Technological developments further complicate efforts to develop unambiguous $C$ budgets, because new measurement techniques capture components of ecosystem fluxes that are different from those available when the terminology in use today was first crafted (Figure 2). Depending on the spatial scale and duration of the measurement program, gas flux-based techniques can capture something that may approximate NEP (for example, from a tower in a homogeneous environment with small dissolved, depositional, and erosional fluxes). A larger-scale airborne boundary layer budget in a mosaic of forest and lakes measures the autochthonous components in both systems, and some amount of aquatic respiration of terrestrially fixed C. Regional to global inverse analyses include even larger contributions from respiration of transported $\mathrm{C}$ and land-use/disturbance fluxes such as from fire (Heimann and others 1998; Bousquet and others 2000). The respiration of imported agricultural products, for example, had to be accounted for to interpret Europe's C budget correctly from atmospheric data (Janssens and others 2003). Most Ccycle research devotes insufficient attention to $C$ fluxes associated with transported particulate and dissolved $\mathrm{C}, \mathrm{VOC}$ and methane emissions, disturbance, harvest, and trade. The variable relationships among $\mathrm{C}$-cycling rates, oxygen transfers, and energy flow are often overlooked.

The scientific community, practical managers, and the general public need clearer definitions of the conceptual components of $\mathrm{C}$ exchange and clearer terms for the fluxes that can be measured. They need to understand the relationships among these frequently divergent ways of viewing the $C$ cycle. Until the related concepts are more clearly aligned with measurements, there is a serious risk for misunderstanding or miscommunication about the impact of human activities on the biosphere, making it difficult to apply the scientific method to the practical management of $\mathrm{C}$ emissions and sequestration.

\section{ACKNOWLEDGEMENTS}

We thank Gus Shaver, Stuart Fisher, and the two anonymous reviewers for their insightful comments.

\section{REFERENCES}

Aber JD, Melillo JM. 1991. Terrestrial ecosystems. Orlando (FL): Saunders College Publishing.

Aber JD, Melillo JM. 2001. Terrestrial ecosystems. 2nd edn. San Diego (CA): Harcourt-Academic Press.

Andrews JA, Schlesinger WH. 2001. Soil $\mathrm{CO}_{2}$ dynamics, acidification, and chemical weathering in a temperate forest with experimental $\mathrm{CO}_{2}$ enrichment. Global Biogeochem Cycles 15:149-62.

Aubinet M, Heinesch B, Yernaux M. 2003. Horizontal and vertical $\mathrm{CO}_{2}$ advection in a sloping forest. Boundary Layer Meteorol 108:397-417.

Aumont $\mathrm{O}$, Orr JC, Monfray P, Ludwig W, Amiotte-Suchet $\mathrm{P}$, Probst J-L. 2001. Riverine-driven interhemispheric transport of carbon. Global Biogeochemical Cycles 15:393-405.

Baldocchi DD. 2003. Assessing the eddy covariance technique for evaluating carbon dioxide exchange rates of ecosystems: past, present and future. Global Change Biol 9:479-92.

Bousquet P, Peylin P, Ciais P, Le Quere C, Friedlingstein P, Tans PP. 2000. Regional changes in carbon dioxide fluxes of land and oceans since 1980. Science 290:1342-6.

Chapin FS III, Matson PA, Mooney HA. 2002. Principles of terrestrial ecosystem ecology. New York: Springer-Verlag.

Ciais P, Janssens J, Shvidenko A, Wirth C, Malhi Y, Grave J, Schulze E-D, Heimann M, Phillips O, Dolman AJ. 2005. The potential for rising $\mathrm{CO}_{2}$ to account for the observed uptake of carbon by tropical, temperate and boreal forest biomes. In: Griffith $\mathrm{H}$, Jarvis $\mathrm{P}$, Eds. The Carbon Balance of Forest Biomes. Milton Park, UK: Taylor and Francis. p 109-150.

Clark DA, Brown S, Kicklighter DW, Chambers JQ, Thomlinson JR, Ni J. 2001. Measuring net primary production in forests: concepts and field methods. Ecol Appl $11: 356-70$.

Cox PM, Betts RA, Jones CD, Spall SA, Totterdell IJ. 2000. Acceleration of global warming due to carbon-cycle feedbacks in a coupled climate model. Nature 408:184-7.

Falge E, Baldocchi D, Tenhunen J, Aubinet $M$, Bakwin $P$, Berbigier P, Bernhofer C, Burba G, Clement R, Davis KJ. 2002. Seasonality of ecosystem respiration and gross primary pro- 
duction as derived from FLUXNET measurements. Agricultural and Forest Meteorology 113:53-74.

Fisher SG, Likens GE. 1973. Energy flow in Bear Brook, New Hampshire: an integrative approach to stream ecosystem metabolism. Ecol Monogr 43:421-39.

Fung IY, Doney SC, Lindsay K, John J. 2005. Evolution of carbon sinks in a changing climate. Proc Nat'l Acad Sci 102:11201-6.

Guenther A. 2002. The contribution of reactive carbon emissions from vegetation to the carbon balance of terrestrial ecosystems. Chemosphere 49:837-44.

Hanson PC, Bade DL, Carpenter SR, Kratz TK. 2003. Lake metabolism: relationships with dissolved organic carbon and phosphorus. Limnol Oceanogr 48:1112-9.

Heimann M, Esser G, Haxeltine A, Kaduk J, Kicklighter DW, Knorr W, Kohlmaier GH, McGuire AD, Melillo J, Moore B, Otto RD, Prentice IC, Sauf W, Schloss A, Sitch S, Wittenberg U. Wurth G. 1998. Evaluation of terrestrial carbon cycle models through simulations of the seasonal cycle of atmospheric $\mathrm{CO}_{2}$ : First results of a model intercomparison study. Global Biogeochemical Cycles 12:1-24.

Howarth RW. 1984. The ecological significance of sulfur in the energy dynamics of salt marsh and marine sediments. Biogeochemistry 1:5-27.

Howarth RW, Teal JM. 1980. Energy flow in a salt marsh ecosystem: the role of reduced inorganic sulfur compounds. Am Nat 116:862-72.

Howarth RW, Michaels AF. 2000. The measurement of primary production in aquatic ecosystems. In: Sala OE, Jackson RB, Mooney HA, Howarth RW, Eds. Methods in ecosystem science. New York: Springer-Verlag. p 72-85.

Howarth RW, Schneider R, Swaney D. 1996. Metabolism and organic carbon fluxes in the tidal, freshwater Hudson River. Estuaries 19:848-65.

Jannasch HW, Mottl MJ. 1985. Geomicrobiology of deep-sea hydrothermal vents. Science 229:717-25.

Janssens IA, Freibauer A, Ciais P, Smith P, Nabuurs GJ, Folberth G, Sehlamadinger B, Hutjes RWA, Ceulemans R, Schulze ED, Valentini D, Dolman AJ. 2003. Europe's terrestrial biosphere absorbs 7 to $12 \%$ of European anthropogenic $\mathrm{CO}_{2}$ emissions. Science 300:1538-1542.

Kesselmeier J, Ciccioli P, Kuhn U, Stefani P, Biesenthal T, Rottenberger S, Wolf A, Vitullo M, Valentini R, Nobre A, Kabat P, Andreae MO. 2002. Volatile organic compound emissions in relation to plant carbon fixation and the terrestrial carbon budget. Global Biogeochemical Cycles 16:10.1029/ $2001 \mathrm{~GB} 001813$.

Kirschbaum MUF, Farquhar GD. 1984. Temperature dependence of whole-leaf photosynthesis in Eucalyptus pauciflora Sieb. ex Spreng. Aust J Plant Physiol 11:519-38.

Kling GW, Kipphut GW, Miller MC. 1991. Arctic lakes and streams as gas conduits to the atmosphere: implications for tundra carbon budgets. Science 251:298-301.

Lieth H. 1975. Modeling the primary productivity of the world. In: Lieth $\mathrm{H}$, Whittaker RH, Eds. Primary productivity of the biosphere. Berlin: Springer-Verlag. p 237-63.

Lindeman RL. 1942. The trophic-dynamic aspects of ecology. Ecology 23:399-418.

Long SP, Moya EG, Imbamba SK, Kamnalrut A, Piedade MTF, Scurlock JMO, Shen YK, Hall DO. 1989. Primary productivity of natural grass ecosystems of the tropics: A Reappraisal. Plant and Soil 115:155-66.
Loreto F, Delfine S, Di Marco G. 1999. Estimation of photorespiratory carbon dioxide recycling during photosynthesis. Aust J Plant Physiol 26:733-6.

Loreto F, Velikova V, Di Marco G. 2001. Respiration in the light measured by $\left(\mathrm{CO}_{2}\right)-\mathrm{C}-12$ emission in $\left(\mathrm{CO}_{2}\right)-\mathrm{C}-13$ atmosphere in maize leaves. Aust J Plant Physiol 28:1103-8.

Lovett GM, Cole JJ, Pace ML. 2006. Is net ecosystem production equal to ecosystem carbon storage? Ecosystems. Forthcoming.

Matson PA, Parton WJ, Power AG, Swift MJ. 1997. Agricultural intensification and ecosystem properties. Science 227:504-9.

Odum EP. 1959. Fundamentals of ecology. Philadelphia: WB Saunders.

Odum HT. 1956. Primary production in flowing waters. Limnol Oceanogr 1:102-17.

Ovington JD. 1962. Quantitative ecology and the woodland ecosystem concept. Adv Ecol Res 1:103-92.

Peterson BJ. 1980. Aquatic primary productivity and the ${ }^{14} \mathrm{C}-\mathrm{CO}_{2}$ method: a history of the productivity problem. Annu Rev Ecol Syst 11:359-85.

Prentice IC, Farquhar GD, Fasham MJR, Goulden ML, Heimann $M$, Jaramillo VJ, Kheshgi HS, Le Quéré $C$, Scholes RJ, Wallace DWR. 2001. The carbon cycle and atmospheric carbon dioxide. Houghton JT et al., editors. Climate Change 2001: The Scientific Basis. Cambridge: Cambridge University Press. p 183-237.

Randerson JT, Chapin FS III, Harden J, Neff JC, Harmon ME. 2002. Net ecosystem production: a comprehensive measure of net carbon accumulation by ecosystems. Ecol Appl 12:937-47.

Richey JE, Melack JM, Aufdenkampe AK, Ballester VM, Hess LL. 2002. Outgassing from Amazonian rivers and wetlands as a large tropical source of atmospheric $\mathrm{CO}_{2}$. Nature 416:617-20.

Richter DD, Markewitz D, Trumbore SE. 1999. Rapid accumulation and turnover of soil carbon in a reestablishing forest. Nature 400:56-8.

Roberts BJ, Owens TG, Ostrom NE, Howarth RW. Aquatic ecosystem respiration rates are not constant over diel cycles: direct quantification using dissolved oxygen concentration and isotopic composition in experimental ponds. Limnol Oceanogr. Forthcoming.

Rodin LE, Bazilevich NI. 1967. Production and mineral cycling in terrestrial vegetation. Edinburgh: Oliver \& Boyd.

Rosenbloom NA, Doney SC, Schimel DS. 2001. Geomorphic evolution of soil texture and organic matter in eroding landscapes. Global Biogeochem Cycles 15:365-81.

Sala OE, Austin AT. 2000. Methods of estimating aboveground net primary productivity. In: Sala OE, Jackson RB, Mooney HA, Howarth RW, Eds. Methods in ecosystem science. New York: Springer-Verlag. p 31-43.

Schimel DS. 1995. Terrestrial ecosystems and the carbon cycle. Global Change Biol 1:77-91.

Schlesinger WH. 1985. The formation of caliche in soils of the Mojave Desert, California. Geochim Cosmochim Acta 49:57-66.

Schlesinger WH. 1990. Evidensce from chronosequence studies for a low carbon-storage potential of soils. Nature 348:232-4.

Schlesinger WH. 1997. Biogeochemistry: an analysis of global change. 2nd edn. San Diego (CA): Academic Press.

Schlesinger WH, Melack JM. 1981. Transport of organic carbon in the world's rivers. Tellus 33:172-87.

Schulze E-D, Heimann M. 1998. Carbon and water exchange of terrestrial systems. In: Halloway, Eds. Asian change in the context of global change. Cambridge (UK): Cambridge University Press. p 145-61. 
Schulze E-D, Lloyd J, Kelliher FM, Wirth C, Rebmann C, Luhker B, Mund M, Knohl A, Milyhukova IM, Schulze W, Ziegler W, Varlagin AB, Sogachev AF, Valentini R, Dore S, Grigoriev S, Kolle O, Panfyorov MI, Tchebakova N, Vygodskaya NN. 1999. Productivity of forests in the Eurosiberian boreal region and their potential to act as a carbon sink-a synthesis. Global Change Biology 5:703-22.

Schulze E-D, Wirth C, Heimann M. 2000. Climate change: managing forests after Kyoto. Science 289:2058-9.

Schulze E-D, Wirth C, Heimann M. 2002. Carbon fluxes of the Eurosiberian region. Environ Control Biol 40:249-58.
Stallard RF. 1998. Terrestrial sedimentation and the carbon cycle: coupling weathering and erosion to carbon burial. Global Biogeochem Cycles 12:231-57.

Wigley TML, Richels R, Edmonds JA. 1996. Economic and environmental choices in the stabilization of atmospheric $\mathrm{CO}_{2}$ concentrations. Nature 379:240-3.

Woodwell GM, Whittaker RH. 1968. Primary production in terrestrial communities. Am Zool 8:19-30.

Woodwell GM, Mackenzie FT. 1995. Biotic feedbacks in the global climatic system: will the warming feed the warming? New York: Oxford University Press. 